\title{
Bacterial Aggregates Within the Epidermis of the Sea Anemone Aiptasia pallida
}

\author{
EDWARD E. PALINCSAR, WARREN R. JONES, JOAN S. PALINCSAR, \\ MARY ANN GLOGOWSKI, AND JOSEPH L. MASTRO \\ Department of Biology, Loyola University, Chicago, Illinois 60626
}

\begin{abstract}
Bacteria in cyst-like aggregates have been observed in the sea anemone Aiptasia pallida. Algal symbionts, common in certain Cnidaria, including Aiptasia, are located in the gastrodermis, while the bacteria described in the present study were found exclusively in the epidermis. They were gram-negative and packed closely together within what appeared to be a single cell. The bacterial sac varied in size according to the number of bacteria it contained. Ultrastructural features of the bacteria included numbers of large vacuoles or inclusions often intertwined with web-like nucleoids in the central region. Aggregates in situ showed a whorled arrangement of the bacteria and maintained this pattern and their structural organization after extrusion from anemone epidermis. A fatty acid profile suggested that the bacteria may belong to the genus Vibrio.
\end{abstract}

\section{Introduction}

Single bacterial cells have often been observed as endosymbionts in cells of many types of organisms. Vesicles containing small numbers of bacteria and Chlorella were found in gastrodermal cells of Hydra (Margulis et al., 1978; Thorington et al., 1979). Wilkinson (1978) cultured and characterized bacteria associated with marine sponges, most of which inhabited the connective tissuelike mesohyl and thus were not usually intimately associated with the sponge cells. Some individual bacteria, as well as cyanobacteria, were located inside sponge cells.

In some animals, endosymbiotic bacteria inhabit specific cell-like structures called bacteriocytes, such as cells noted by Vacelet (1975) in the marine sponge, Verongia. Palincsar et al. (1988) found many bacteria inside aggre-

Received 12 October 1988; accepted 31 May 1989 gates in the epidermis of Aiptasia pallida. Peters et al. (1983) and Peters (1984) identified bacteria in "basophilic ovoid bodies" in septa and calicoblast tissue of Acropora palmata and A. cervicornis, and in mesoglea of Porites astreoides in the Caribbean. Gills of Spisula subtruncata have bacteriocytes containing a "bacteriophore" with over 200 bacteria (Soyer et al., 1987). Because we found no nuclei directly associated with bacterial aggregates in A. pallida, and the origin of the membrane surrounding the bacteria is uncertain at present, we will use the term bacterial aggregate for large numbers of bacteria packed together, bounded by a discrete membrane, which are located either intracellularly or extracellularly.

The bulk of trophosome tissue in vestimentarian tube worms, Riftia pachyptila, of the Galapagos Rift was observed by Jones (1981) to be mostly bacteria; on inspection under the electron microscope, Cavanaugh (1983) found that these bacteria were located in bacteriocytes. The tissues of other smaller pogonophorans not from hydrothermal vent communities also contained bacteria, mostly within host cells (Southward et al., 1981). The gutless marine oligochaete Phallodrillus (Felbeck et al., 1983) contained bacteria within its tissues. In addition, Cavanaugh (1983) described bacteriocytes in gills of the hydrothermal vent clams, Calyptogena magnifica, C. pacifica, two non-vent clams, Solemya velum and Lucinoma annulata, and an additional pogonophoran. Fischer and Hand (1984) studied bacteriocytes in Lucina floridana, a clam living in an aerobic high-sulfide environment. Dando et al. (1985) found several species of lucinid clams inhabiting low sulfide environments. The clams contained bacterial symbionts that accumulated sulfur as an energy source. Bouvy et al. (1986) and Soyer et al. (1987) described packets of bacteria which they 
termed bacteriophores, in Spisula subtruncata, a surf clam living in a highly aerobic environment. These bacteria were of two types, were spatially separated in the gill, and used reduced nitrogen and sulfur compounds as energy sources.

Although it is well known that the gastrodermis of $A$. pallida harbors the symbiotic dinoflagellate Symbiodinium microadriaticum, here we describe bacteria in aggregates at both light and electron microscopic levels, in a different location in the epidermis of the anemone Aiptasia pallida. In addition, we have begun chemical characterization of the bacteria with fatty acid analysis. We have also studied control of the bacterial population in situ to learn whether interrelationships exist between population levels of the two different symbionts, algal and bacterial.

\section{Materials and Methods}

Individuals of Aiptasia pallida were obtained from Carolina Biological Supply Company (Burlington, North Carolina 27215). The anemones were kept in 38-1 aquaria in Instant Ocean (Aquarium Systems, Mentor, Ohio 44060) made with tap water at a specific gravity of 1.020 at $25^{\circ} \mathrm{C}$. The anemones were cultured under fluorescent light with $16 \mathrm{~h}$ of light and $8 \mathrm{~h}$ of darkness, using a 35 W GE Lite-white and a $40 \mathrm{~W}$ Sylvania Grolux fluorescent tube at an intensity of $24 \mu \mathrm{Em}^{-2} \mathrm{~s}^{-1}$, measured with a LI Photometer Model LI185A with an underwater sensor (Lambda Instrument Corporation). The anemones were fed to repletion with Artemia nauplii (San Francisco Bay Brand, Newark, California 94560) twice a week. The $\mathrm{H}_{2} \mathrm{~S}$ level in the culture tank was $0.015 \mathrm{mg} / \mathrm{l}$ (Hach kit \#2238); the sulfate level was $200 \mathrm{mg} / \mathrm{l}$ (Hach kit \#2251); the nitrate level was $7.95 \mathrm{mg} / \mathrm{l}$ and the nitrite level was $0.048 \mathrm{mg} / \mathrm{l}$, measured with Model NI 14 nitrate and nitrite kit (Hach Company, Loveland, Colorado 80539). A. pallida were maintained for two years in culture. The tentacles contained clear ovoid structures as seen under the dissecting microscope. (In the ensuing 2 years, we have seen over 200 anemones with these structures.) Higher magnification revealed bacteria inside the ovoid structures. New orders of Aiptasia from Carolina, and from Ward's Natural Science Establishment, examined immediately upon arrival, also contained aggregates in the tentacular epidermis. Samples of Aiptasia pallida from the Shedd Aquarium, Chicago, and from Bermuda were examined; no aggregates were found (S. Kenney and M. Lesser, pers. comm.). A. pallida individuals collected immediately before shipment from their natural habitat at Morehead City, North Carolina by Lawrence Wallace (Carolina Biological Supply Company) had the largest numbers of bacteria seen to date, averaging 75 ag- gregates per sample (sampled according to methods given for antibiotic sensitivity determinations).

For electron microscope studies, 10 anemones containing aggregates were anesthetized in $3 \% \mathrm{MgSO}_{4}$ for 1 h. Tentacle tips 2-4 mm long were clipped and immersed for $1 \mathrm{~h}$ at $4^{\circ} \mathrm{C}$ in a modified Karnovsky's fixative (2.5\% glutaraldehyde and $2 \%$ paraformaldehyde, Karnovsky, 1967) made up in Instant Ocean, postfixed in $2 \%$ osmium tetroxide at room temperature for $30 \mathrm{~min}$, dehydrated in a graded series of acetone, and embedded in Epon 812. Sections were cut on an LKB Nova Ultratome, stained with uranyl acetate (Hayat, 1969) and lead citrate (Reynolds, 1963), and viewed in a JEOL model $1200 \mathrm{EX}$ transmission electron microscope at $80 \mathrm{kV}$. One $\mu \mathrm{m}$ sections from the same preparations were cut and stained in toluidine blue for light microscopic evaluation.

Estimates of numbers of bacteria inside a small, typical (20 $\mu \mathrm{m}$ diameter) aggregate were made by comparing the volume of a aggregate with that of a bacterium, according to methods described by Boatman (1986). Bacterial vacuole or inclusion numbers, diameters, and volumes were measured with the Bioquant Image Analysis System ( $R$ \& M Biometrics, Inc., Nashville, Tennessee 37209) with Hipad electronic digitizer. All vacuoles in the sample were counted regardless of level of section through the sphere of the vacuole.

Tentacles were removed and placed in two washes of Instant Ocean to obtain isolated aggregates for observation, analysis, and culture. This procedure stimulated the release of intact aggregates into the medium. The isolated aggregates were also washed twice in Instant Ocean to minimize collection of any surface microflora. Both intact aggregates and individual bacteria released from broken aggregates were stained with Gram's stain for type of wall structure and with Sudan Black for lipids (Humason, 1972).

A sample of isolated aggregates was lyophilized and sent to Microbial ID, Inc. (Newark, Delaware 19711) for fatty acid analysis by gas chromatography. The cellular fatty acid profile, showing types and relative amounts of fatty acids by chain length, saturation, and side groups, was compared to a Hewlett Packard computer data bank of fatty acid profiles of bacterial genera and species. Identification by fatty acid analysis is comparable to that by rapid biochemical strips, is effective for far more genera, and is often more specific than biochemical tests. Matching of similarities between the sample and known bacterial species provided a reliable index to the identification of bacteria (Moss and Lewis, 1967; Miller, 1984; Sasser et al., 1984).

The effects of antibiotics on the control of the numbers of bacterial aggregates of Aiptasia were determined. 

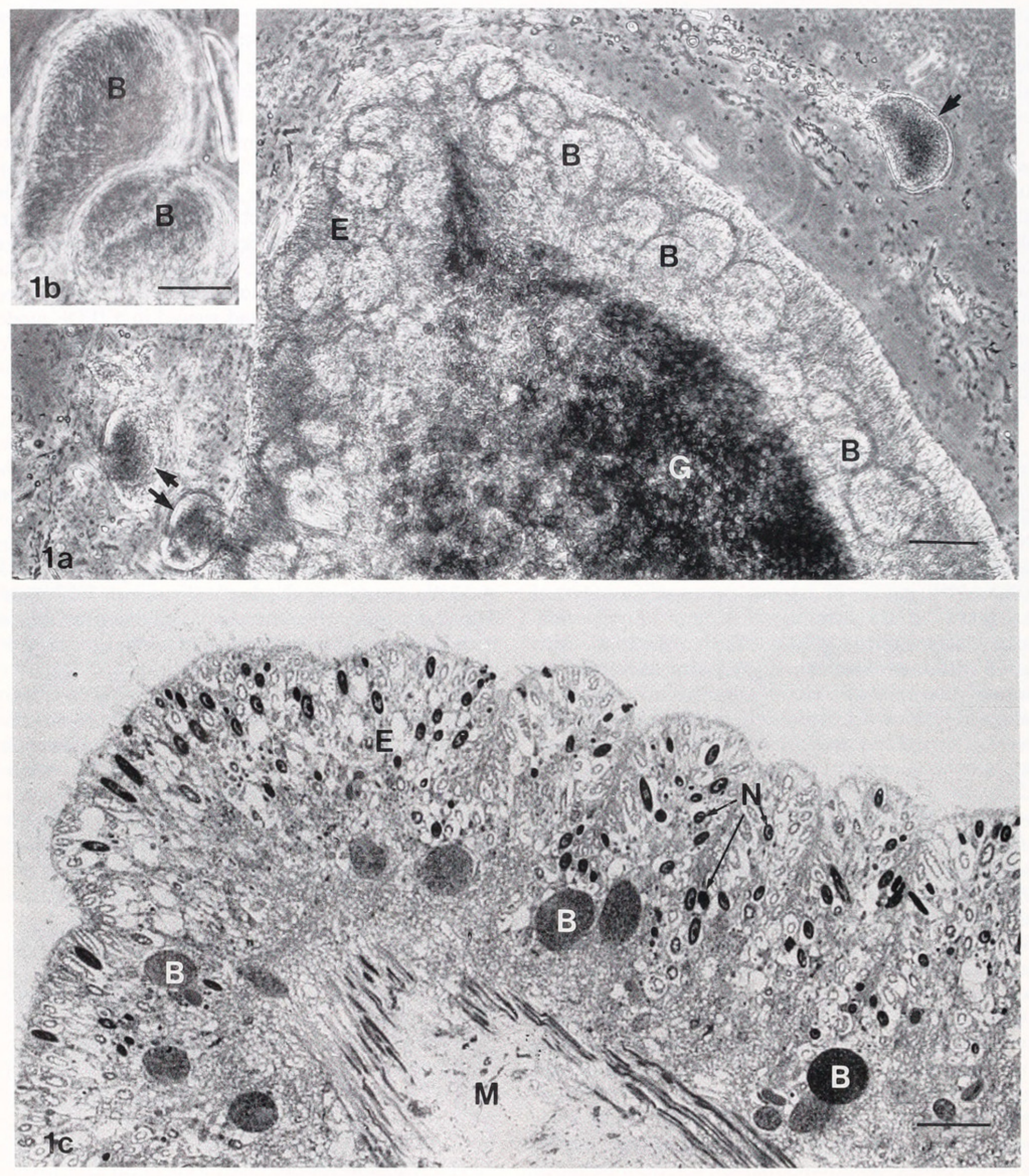

Figure 1. A. Phase contrast view of living tentacle containing numerous balloon-like aggregates in Aiptasia pallida epidermis. Note extruded aggregate (arrow) outside the tentacle. Bar $=100 \mu \mathrm{m}$. B. Phase contrast view of two extruded aggregates. $\mathrm{Bar}=25 \mu \mathrm{m}$. C. Light microscope view of toluidine blue stained section of epidermis of anemone tentacle showing aggregates among epidermal cells. Aggregate (B), epidermis (E), gastrodermis containing symbiotic dinoflagellates (Symbiodinium microadriaticum) (G), mesoglea (M), nematocyst $(\mathrm{N})$. Bar $=100 \mu \mathrm{m}$. 

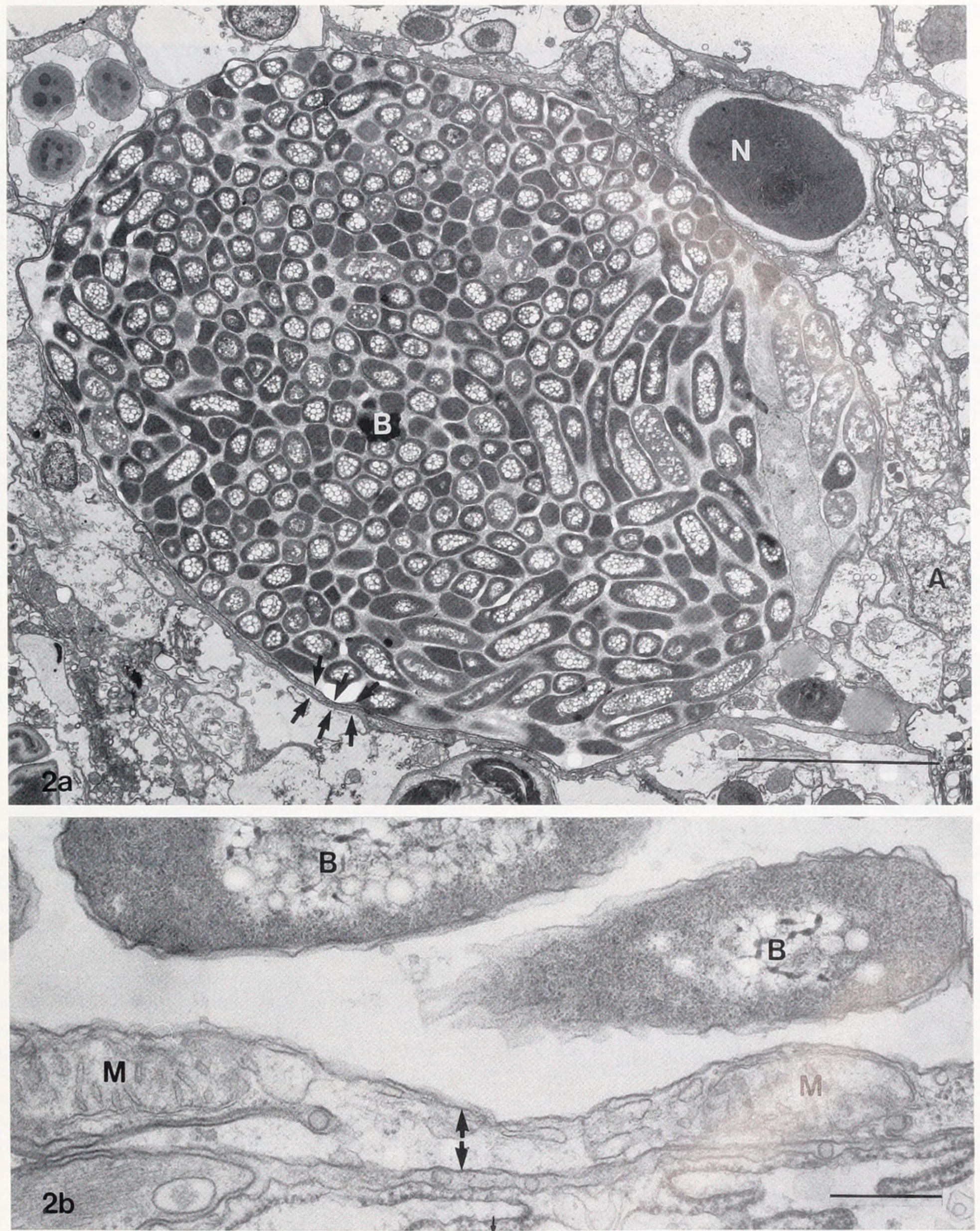

Figure 2. A. Transmission electron microscope section of entire aggregate containing numerous bacteria. Note thin membrane surrounding aggregate and associated anemone membranes (facing arrows). Several anemone cells abut the bacterial enclosure. Anemone epidermal nucleus (A), aggregate (B), nematocyst $(\mathrm{N})$. Bar $=5.0 \mu \mathrm{m}$. B. Portion of aggregate-anemone interface. Note small amount of anemone cytoplasm with mitochondria between membrane of aggregate vacuole and plasma membrane. Bacteria (B), mitochondrion (M); Arrows span width of anemone cytoplasm. Bar $=0.5 \mu \mathrm{m}$. 


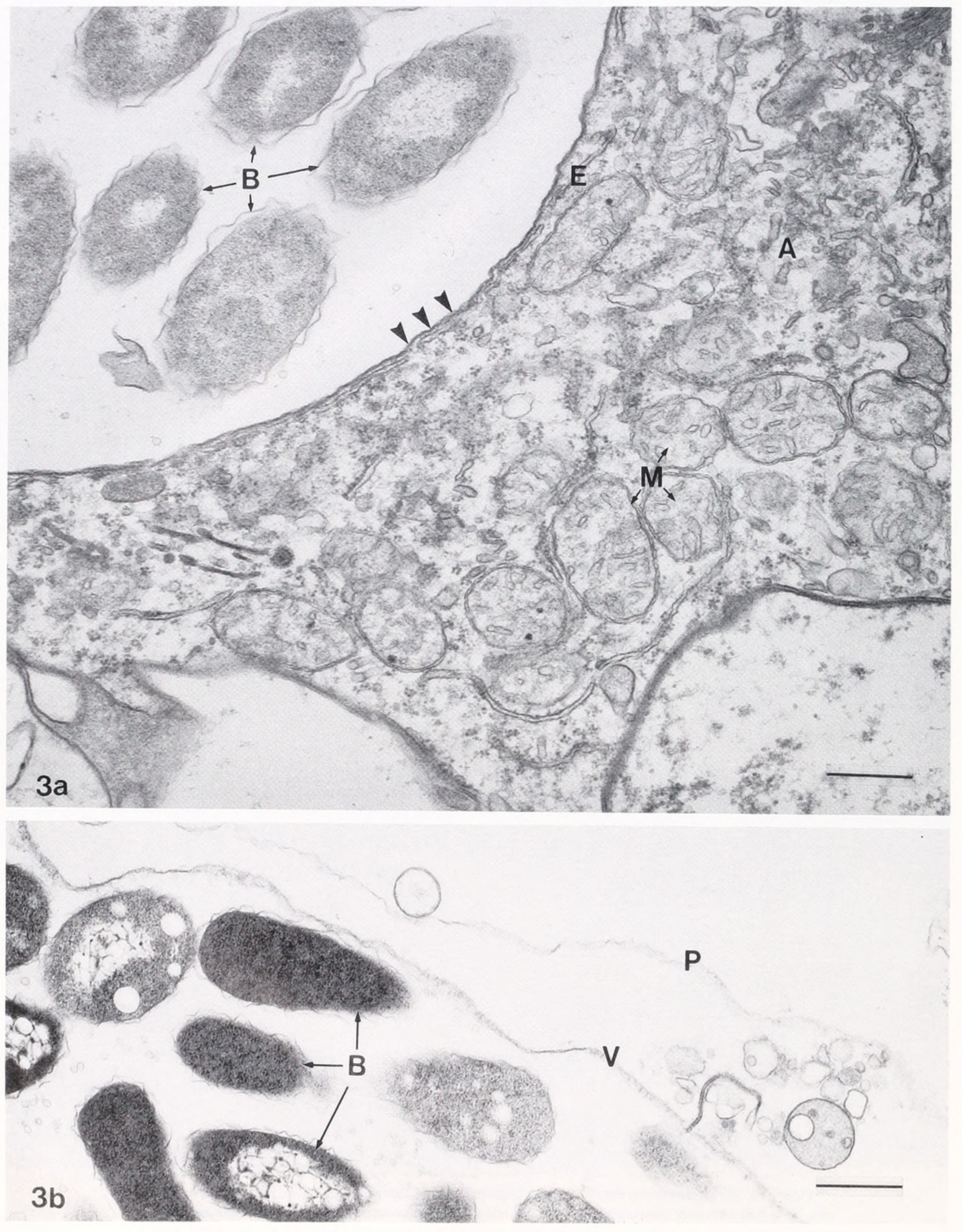

Figure 3. A. Portion of small aggregate. There is a relatively large amount of anemone cytoplasm in this specimen. Endoplasmic reticulum (E). Bar $=0.5 \mu \mathrm{m}$. B. High power view of membranes of isolated 
Three aquaria, each containing 10 anemones with their aggregates, were set up. One contained $125 \mathrm{mg} / \mathrm{ml}$ streptomycin sulfate in Instant Ocean, a second contained 25 $\mathrm{mg} / \mathrm{ml}$ chloramphenicol (d'Agostino, 1975), and a third contained Instant Ocean alone, as a control. Conditions were the same as for the stock cultures. Aggregate populations were sampled every 5 days over a 3 -week period by clipping a tentacle from each anemone and counting bacteriocytes visible in the epidermis on one side of the tentacle from the tip toward the base for $0.6 \mathrm{~mm}$.

To determine whether decreased populations of Symbiodinium would affect the population of bacteria, anemones were placed in 31 of aerated Instant Ocean at $17^{\circ} \mathrm{C}$ that contained $10^{-3} M$ 3-(3,4-dichlorophenyl)-1,1dimethylurea (DCMU) (Sigma Chemical Company) in light of $580 \mu \mathrm{Em}^{-2} \mathrm{~s}^{-1}$ intensity from 2 GE $120 \mathrm{~W}$ reflector floodlights, for 3 days. This procedure was adapted from the technique of Pardy (1976) which, when applied over a longer period of time, or at a higher light intensity, resulted in nearly total destruction of algal symbionts. Pardy used this procedure to obtain aposymbiotic cnidarians for controls in symbiosis experiments. Aggregates were counted using the same procedure as that used for the antibiotic sensitivity determinations. Cell numbers of $S$. microadriaticum were sampled by counting the cells found in a $0.2-\mathrm{mm}$ transect. The distribution of $S$. microadriaticum was homogeneous in the tentacle preparations.

\section{Results}

In intact tentacles viewed under phase contrast microscopy, aggregates appeared as lucent spherical bodies within the epidermis of Aiptasia pallida (Fig. 1a). Their position varied from near the mesoglea to the free surface of the epidermis. While the aggregates were most common at the tips of anemone tentacles, they were also observed proximally on the tentacles, on the oral disc, and at low density throughout the column of the anemones. The size of aggregates shown in Figures 1-3 varied from about 10 to $100 \mu \mathrm{m}$. The number of aggregates varied greatly from one anemone to another. Bacterial aggregates (counted according to the method for antibiotic sampling) from each of a sample of 44 different anemones showed that $6(14 \%)$ anemones had no aggregates in the area of the sample, and $10(23 \%)$ anemones had 25 or more aggregates in the same sample area. The mean number of aggregates for all 44 anemones was 14.86 per $0.6 \mathrm{~mm}$ sample. Under higher magnification, the aggregates had a characteristic "finger print" appearance due to the tendency of adjacent rod-shaped bacteria to orient parallel to each other, producing a whorled pattern (Fig. 1b). The organization of the aggregate, and the characteristic whorled arrangement of the bacteria, was maintained after isolation of the aggregate from the epidermis.

Toluidine blue-stained aggregates seen in tentacular epidermis of $A$. pallida under light magnification appeared as dark oval spots in the epidermal layer (Fig. 1c). Cnidocytes, ciliated cells, and other cells normally present in the epidermis surrounded the aggregates. An aggregate $20 \mu \mathrm{m}$ in diameter contained up to about 1200 individual bacteria.

Examination of the ultrastructure of an aggregate in its place in anemone epidermis shows the bacteria packed closely together (Fig. 2a). The tendency of the bacteria to remain parallel to one another within the aggregate results in many adjacent longitudinal or many adjacent cross sections. Even this relatively small aggregate is many times larger than the epidermal cells of the anemone peripheral to it. Membranes of the anemone cells intersect the thin dark aggregate membrane and either merge with it or run parallel to it for some distance. The interface between the bacteria-containing structure and the anemone cell may contain cytoplasm and cell organelles (Fig. 2b). Very small aggregates may be surrounded by a wide band of cytoplasm (Fig. 3a), containing the usual complement of cell organelles, including a layer of endoplasmic reticulum parallel to the aggregate. Following extrusion from the anemone epidermis, isolated aggregates are surrounded by a double membrane strong enough to withstand the stress of up to 6 transfers to fresh Instant Ocean (Fig. 3b). Occasionally, when aggregates ruptured, the bacteria exhibited pronounced motility on contact with seawater.

The size of the aggregate was close to the size of the intergrid space of the section support medium so that the ultrastructure of entire full-sized aggregates could not be observed. The size of the aggregate (observed range about $10-100 \mu \mathrm{m}$ ) was determined by the number of bacteria it contained, since the bacteria were packed closely together in every aggregate observed.

The individual bacteria of the aggregates were gramnegative rods, averaging $1.0 \mu \mathrm{m} \times 4.0 \mu \mathrm{m}$ in size. Viewed

aggregate. Disruption of anemone cytoplasm was not due to fixation, since the same procedures were used on all tissues, but probably due to mechanical disruption during handling of individual aggregates. Bacteria (B), anemone cytoplasm (A), mitochondrion (M), membranes of aggregate (P) and (V). Arrowheads indicate membrane of aggregate vacuole. Bar $=0.5 \mu \mathrm{m}$. 
under the electron microscope, the cytoplasm contained numerous electron-lucent vacuoles or granules that were not membrane bound (Fig. 4a, b). Calculations from measurements of 370 vacuoles showed that they occupied up to $6.66 \pm 0.74 \%$ of the volume of the cell, appeared randomly distributed and had a mean diameter of $162 \pm 6.98 \mathrm{~nm}$. Using the light microscope, we observed the bacteria accumulating the lipid stain, Sudan Black. Web-like nucleoid material was centrally located. The bacterial wall had the layered structure typical of Gram-negative bacteria, and stained negatively in Gram's stain. The outer wall of the bacterial cell appeared loose and undulating or ridged, leaving regular spaces between the wall and cell membrane (Fig. 4a, b). This appearance may be a fixation artifact in gram negative bacteria, according to studies of $E$. coli, as described by Dubochet et al. (1983). Bacteria were regularly observed to be dividing by fission (Fig. 4c). The bacteria were observed only within aggregates in A. pallida, and we did not observe single bacterial cells in, or between, anemone cells. Some aggregates observed in electron microscope sections also contained one or two less electrondense bacteria that were about twice as large as the other bacteria. Southward (1986) also observed two different types of bacteria in the same aggregate in deep sea thyasirids. Two types of bacteria were also seen by Soyer $e t$ al. (1987), although not within the same bacteriophore.

Aggregate fatty acid analysis showed 11 fatty acids with chains from 9 to 18 carbons in length. Comparison of the aggregate fatty acid profile with the Hewlett Packard bacterial classification data bank indicated most similarities to the genus Vibrio (pers. comm., Microbial ID). Comparisons of aggregate fatty acids with Vibrio mimicus (Microbial ID) and V. anguillarum (Boe and Gjerde, 1980) were made by setting the 16-carbon straight chain fatty acid in all three samples to $100 \%$. Amounts of fatty acids having different chain lengths were calculated as percentages of this base value (Table I).

During treatment with chloramphenicol, the aggregate population decreased from 17.5 aggregates per $0.6 \mathrm{~mm}$ sample of one side of a tentacle tip from each of 10 anemones, to 5.0 in 5 days, a decrease of $75 \%$ as compared to the control, reaching a minimum of 1.4 after 10 days. In streptomycin, the number of aggregates decreased by $50 \%$ after 10 days from 14.9 to 7.8 , and reached a minimum of 6.0 after 20 days. After 20 days, the number of aggregates was 4 times lower in chloramphenicol than in streptomycin. On day 1 , the means of the three groups showed no significant differences (using one-way analysis of variance, the F statistic is 0.20 and the $P$-value is 0.82 ). Also, this and subsequent observations on the control group made on days $1,5,10,16$, and 20, showed no significant changes in the mean of the control group over this time period (using one-way analysis of variance, the F statistic is 0.15 and the $P$-value is 0.96 ). However, there was a sharp decline in both the mean and the variance of the number of bacteriocytes in the group treated with chloramphenicol when compared to the control group. A two-sample t test for independent samples with unequal variances, using the Satterwaite approximation for the degrees of freedom in computing the $P$-value, indicated a significant difference in the mean number of aggregates in the anemones undergoing chloramphenicol treatment when compared to the control group of the fifth day $(\mathrm{t}=4.54$, d.f. $=17, P$-value $<0.0001)$. Separate $\mathrm{t}$ tests comparing these groups on days 10,16 , and 20 also indicated significant differences (on the 20th day, $\mathrm{t}$ $=4.28$, d.f. $=9, P$-value $=0.002$ ). The same method comparison showed no significant difference in the means of the streptomycin group and the control group until the 20th day. (On the 20th day $\mathrm{t}=2.18$, d.f. $=17$, $P$-value $=0.043$ ). Nonparametric methods, using MannWhitney statistics in place of the t statistics, gave similar results. For example, the difference in the control and the streptomycin group after 20 days remained statistically significant $(P$-value $=0.017)$. The anemones undergoing chloramphenicol treatment began to show deleterious effects during the third week, indicated by tentacular retraction.

Following treatment with light and DCMU, much of the Symbiodinium population was lost and the number of aggregates increased, from a mean of $8.8 \pm 2.61$ per $0.6 \mathrm{~mm}$ tentacle sample before treatment, to $11.3 \pm 4.86$ after three days of treatment, to $27.4 \pm 3.15$ three days following return to normal culture conditions. Mean numbers of Symbiodinium decreased during treatment from $26.6 \pm 1.38$ to $11.6 \pm 1.73$, and then to a further reduction of $5.2 \pm 1.70$ one week later. Seven days following the return to normal culture conditions, the number of aggregates was still elevated $(15.1 \pm 3.33$ per tentacle). The standard errors are relatively high because of the previously mentioned great variation in numbers of aggregates from one anemone to another. Even so, t-test values demonstrated that the mean number of aggregates per tentacle at the beginning of the experiment was significantly different at the 0.01 confidence level from the mean number at day 6 and day 10 .

\section{Discussion}

Bacteria in the aggregates from Aiptasia pallida specimens were not individually surrounded by host vacuoles and host cytoplasm as observed by Cavanaugh (1983) in Solemya velum, Riftia pachyptila and Calyptogena magnifica or Fischer and Hand (1984) in Lucina floridana but instead the bacteria were clumped together in one 

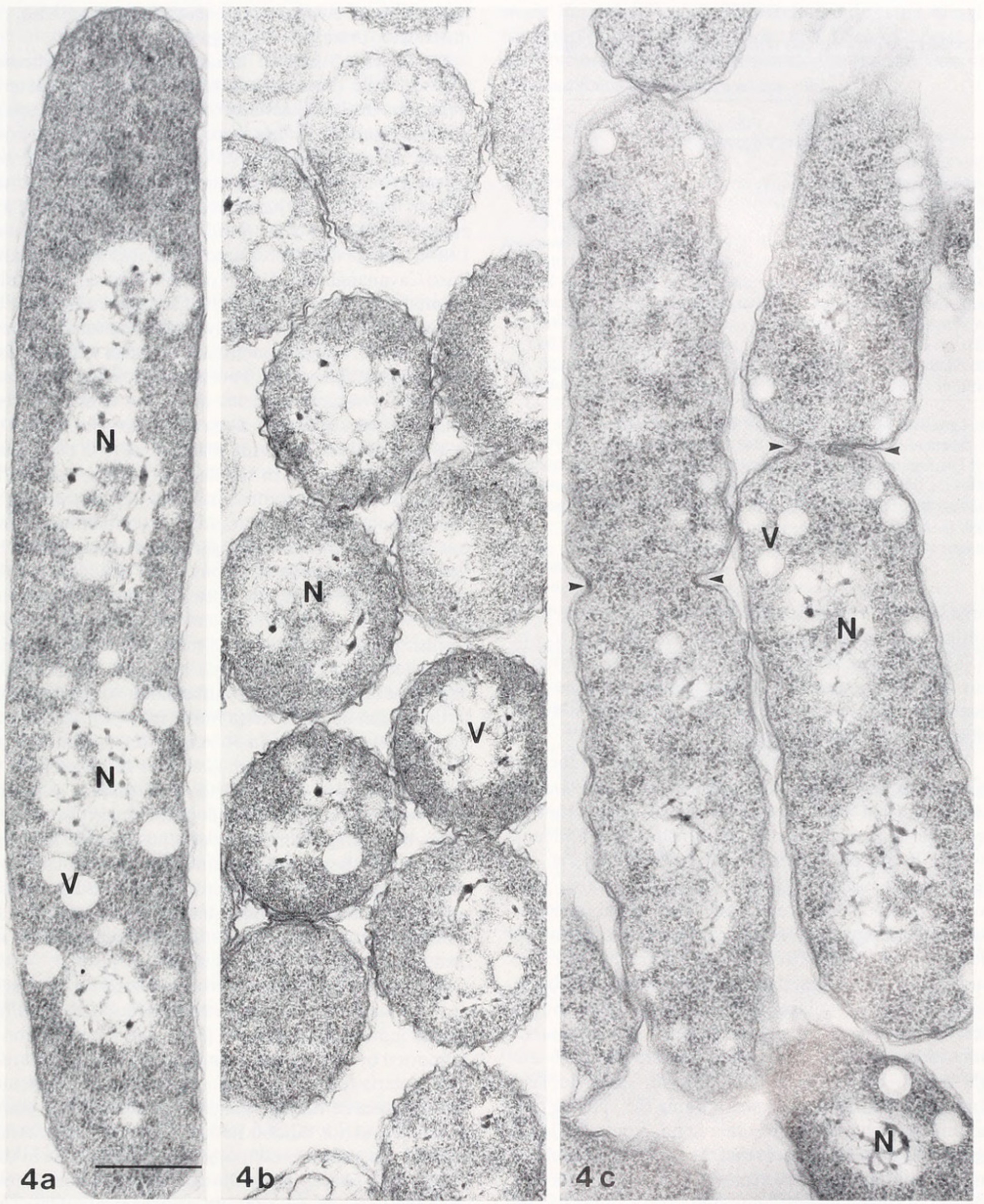

Figure 4. A. Longitudinal section of bacterium inside aggregate. B. Cross sections of bacteria in aggregate. C. Longitudinal section of bacteria undergoing fission (arrowheads) inside aggregate. Nucleosome $(\mathrm{N})$, vacuole $(\mathrm{V})$. Bar $=0.5 \mu \mathrm{m}$. 
Table I

Percentage distribution of fatty acids of aggregates found in Aiptasia

Fatty acids as a percent of 16-C fatty acid

Aggregate Vibriomimicus ${ }^{1} \quad$ V. anguillarum $^{2}$

\begin{tabular}{lccc}
$\begin{array}{c}\text { Fatty acid } \\
\text { chain length }\end{array}$ & & & \\
$9: 0^{3}$ & 5.30 & 0 & 0 \\
$12: 0$ & 8.00 & 0 & 16.50 \\
$12: 03 \mathrm{OH}$ & 4.81 & 13.80 & 0 \\
$14: 0$ & 23.84 & 20.76 & 32.10 \\
$15: 0$ anteiso & 11.29 & 0 & 1.90 \\
$16: 0$ iso & 14.62 & 5.90 & 28.90 \\
$16: 1$ cis 9 & 117.32 & 128.00 & 251.00 \\
$16: 0$ & 100.00 & 100.00 & 100.00 \\
$18: 1$ cis 9 & 33.02 & 0 & 62.50 \\
$18: 0$ & 19.09 & 6.92 & 9.10 \\
\hline
\end{tabular}

' Data from Microbial ID Hewlett Packard data base.

${ }^{2}$ Mean of 10 subcultures from Boe and Gjerde (1980).

${ }^{3}$ The first number indicates the carbon chain length; the number following the colon gives the number of double bonds; any notations to the right give modifications in structure from a straight chain fatty acid.

large vacuole. The appearance of the aggregate was more similar to those described by Peters (1983), Bouvy et al. (1986), and Soyer et al. (1987). The presence of numerous dividing bacteria (Fig. 4a) inside the aggregate indicated that they were metabolically active and that the aggregate was not a static cyst.

The data suggest that there are two possible theories of the structural origin of aggregates in A. pallida. Our observations of small aggregates (Fig. 3a) suggest that the aggregate is an anemone cell that is distorted by a vacuole swollen by the multiplication of invading bacteria. Micrographs of isolated aggregates also showed that there were organized structures between two membranes surrounding the aggregate. Figure 3 a shows endoplasmic reticulum next to the bacterial compartment. Chesnick and Cox (1986) suggest that the membranes of the bacteriophore in the dinoflagellate Peridinium baltica may be derived from endoplasmic reticulum. These observations indicate that the aggregate enclosure is not of bacterial origin, but an anemone cell with the cytoplasm stretched into a thin shell surrounding the vacuole containing the bacteria. On the other hand, pictures of larger aggregates (Fig. 2a) indicate that the bacteria are enclosed in a membrane separate from the anemone structure. Figure 2a shows several anemone cells around the periphery of the bacterial enclosure, none of which enclose the aggregate. The great size difference between anemone cells and aggregates makes it seem unlikely that an anem- one cell could enlarge to the necessary degree. Also, no nuclei were observed in aggregates.

No series of parallel intracytoplasmic membranes such as those characteristic of photosynthetic bacteria were seen in the bacteria of $A$. pallida. In this respect, bacteria from $A$. pallida were similar to bacteria from marine sponges (Vacelet, 1975; Wilkinson, 1978), R. pachyptila, other vestimentiferans, the clams Solemya velum, C. magnifica, C. pacifica, Lucinoma annulata (Cavanaugh, 1983), and L. floridana (Fischer and Hand, 1984), none of which possessed internal lamellae. In contrast, Cavanaugh et al. (1981) described intracytoplasmic membranes in bacteria in formalin-fixed trophosome of R. pachyptila. In Hydra, individual bacterial symbionts are located in the gastrodermis in contrast to the epidermal location in Aiptasia (Thorington et al., 1979). Moreover, the symbiotic vesicles in Hydra contained very small numbers of both bacteria and Chlorella. Studies by Wilkerson (1980) conclude that the bacteria contribute to phosphate uptake in this organism. The bacteria in A. pallida differ from those in other marine animals in confinement to the epidermis and in containing numerous bacteria within a single aggregate except as noted by Peters (1983) in corals and Bouvy et al. (1986) in clams.

The vacuoles or granules located in the bacterial cytoplasm were a constant feature of the bacterium. Similar inclusions have been found in many other bacteria, and their contents have even been analyzed. Jones (1981) and Hand (1987) identified intracellular vacuoles similar to those seen in the bacteria found in A. pallida, as locations of sulfur deposits in R. pachyptila. A common intracellular inclusion, which is similar in appearance to vacuoles found in bacteriocytes of $A$. pallida, is associated with accumulation of poly-b-hydroxybutyrate. Lack of limiting membranes around the vacuoles does indicate that they might contain lipids. Sudan Black lipid staining under the light microscope also suggests this possibility. Lack of granular material in the vacuoles after electron microscope preparation procedures used indicated that they did not contain glycogen.

The computer matching process, based on fatty acid analysis, suggested that the bacterium found in $A$. pallida was a member of the genus Vibrio. This identification is supported by our structural findings, although the particular bacteria found in $A$. pallida are large for this genus. The bacteria in the aggregates were consistently gramnegative, and not variable in their Gram staining characteristics. Therefore, even though the bacteria were in various growth phases inside the aggregate, the consistency of staining shows that the cells are Gram-negative. This conclusion is further confirmed by the typical layered appearance of the cell wall (Fig. 4), not found in Grampositive bacteria. Moreover, members of the genus $\mathrm{Vi}$ - 
brio are frequently found in close association with marine animals, are Gram-negative, and can be straight rods. Most Vibrio require $\mathrm{Na}^{+}$ions for growth, often grow at $20^{\circ}-30^{\circ} \mathrm{C}$, and tolerate moderately alkaline conditions. These requirements are consistent with the marine environment of the aggregates. Some species store poly-b-hydroxybutyrate in intracellular granules. Many species form flagella, but others do not. They are sensitive to chloramphenicol and streptomycin, as were the bacteria in the aggregates. Vibrio is also sensitive to a relatively wide range of other antibiotics (Baumann et al., 1984).

Because Aiptasia benefit from the presence of Symbiodinium, the possibility that changes in the bacterial population might affect the Symbiodinium population and consequently affect the well-being of Aiptasia, suggests an additional factor to be considered in studying how changes in one population may affect the other. It is unknown whether the increase of aggregates in anemones subjected to light-DCMU treatment was due to the use of substances from damaged Symbiodinium, or possibly to the increased availability of some substance not used by the decreased population of Symbiodinium. Decrease in bacterial numbers after 10 days suggests that the bacteria may have been using nutrients obtained from $S$. microadriaticum cells as they disintegrated. We have not observed detrimental effects of bacterial colonies on $A$. pallida. Individuals may develop shortened, thickened tentacles, but this condition has not been associated with certainty with increased numbers of aggregates, like Peters (1984) has associated pathological conditions in corals with the presence of bacteria.

Work is in progress to isolate and culture the bacteria, characterize them physiologically and biochemically, and determine their metabolic relationships in $\mathrm{A}$. pallida. We now have a three-way system to study. The interrelationships between Aiptasia and Symbiodinium are already well established. The combination of bacterial, dinoflagellate, and anemone cells living together suggests curious biochemical and ecological interrelationships, knowledge of which may prove useful as a model system in cellular ecology.

\section{Acknowledgments}

The authors express grateful appreciation to the following: Drs. Myron Sasser and Margaret Roy of Microbial ID for helpful advice on sample preparation for the fatty acid analysis; Dr. Gerald Funk of the Department of Mathematics, Loyola University of Chicago, for statistical treatment of results of the antibiotics experiment; Lawrence Wallace of Carolina Biological Supply Company for freshly collected Aiptasia pallida from the sea- shore; Susan Kenney of the Shedd Aquarium in Chicago for samples of Aiptasia pallida; and Michael Lesser of the University of Maine at Orono for examination of Aiptasia from Bermuda.

\section{Literature Cited}

d'Agostino, A. 1975. Antibiotics in cultures of invertebrates. Pp. 109_ 133 in Culture of Marine Invertebrate Animals, W. L. Smith, ed. Plenum Press, New York.

Baumann, P., A. L. Furniss, and J. V. Lee. 1984. Genus I. Vibrio. Pp. 518-537 in Bergey's Manual of Systematic Bacteriology, Vol. I, J. G. Holt, ed. Williams \& Wilkins, Baltimore.

Boatman, E.S. 1986. Digitizing and Quantitation. Chap. 13 in Ultrastructural Techniques for Microorganisms, H. C. Aldrich and W. J. Todd, eds. Plenum Press, New York.

Boe, B., and J. Gjerde. 1980. Fatty acid patterns in the classification of some representatives of the families Enterobacteriaceae and $\mathrm{Vi}$ brionaceae. J. Gen. Microbiol. 116: 41-49.

Bouvy, M., G. Cahet, F. deBilly, J. Soyer, M.-O. Soyer-Gobillard, and C. Thiriot-Quievreux. 1986. Sur la presence de bacteries dans las branchie d'un mollusque bivelve littoral Spisula subtruncata. C. $R$. Acad. Sci. Paris 303: 257-262.

Cavanaugh, C. M., S. L. Gardiner, M. L. Jones, H. W. Jannasch, and J. B. Waterbury. 1981. Prokaryotic cells in the hydrothermal vent tube worm Riftia pachyptila Jones: possible chemoautotrophic symbionts. Science. 213: 340-342

Cavanaugh, C. M. 1983. Symbiotic chemoautotrophic bacteria in marine invertebrates from sulphide rich habitats. Nature $\mathbf{3 0 2 ( 3 )}$ : $58-61$.

Chesnick, J. M. and E. R. Cox. 1986. Specialization of endoplasmic reticulum architecture in response to a bacterial symbiosis in Peridinium balticum. J. Phycol. 22: 291-298.

Dando, P. R., A. J. Southward, E. C. Southward, N. B. Terwiliger, and R. C. Terwiliger. 1985. Sulphur-oxidising bacteria and haemoglobin in gills of the bivalve mollusc Myrtea spinifera. Mar. Ecol. Prog. Ser. 23: 85-98.

Dubochet, J., A. W. McDowell, B. Menge, E. N. Schmid, and K. G. Lickfeld, 1983. Electron microscopy of frozen-hydrated bacteria. J. Bacteriol. 155: 381-390.

Felbeck, H., G. Liebezeit, R. Dawson, and O. Giere. 1983. $\mathrm{CO}_{2}$ fixation in tissues of marine oligochaetes (Phallodrillus leukodermatus and $P$. planus) containing symbiotic chemoautotrophic bacteria. Mar. Biol. 75: 187-191.

Fischer, M. R. and S. C. Hand. 1984. Chemoautotrophic symbionts in the bivalve Lucina floridana from seagrass beds. Biol. Bull. 167: $445-459$

Hand, S. C. 1987. Trophosome ultrastructure and the characterization of isolated bacteriocytes from invertebrate-sulfur bacteria symbioses. Biol. Bull. 173: 260-276.

Hayat, M. A. 1969. Uranyl acetate as a stain and a fixative for heart tissue. Proc. 27th Ann. Meeting Electron Microsc. Soc. Am. Claitors Publ., Baton Rouge. P. 412.

Humason, G. L. 1972. Animal Tissue Techniques. Freeman, San Francisco.

Jones, M. L. 1981. Riftia pachyptila Jones: observations on the vestimentiferan worm from the Galapagos Rift. Science. 213: 333-336.

Karnovsky, M. 1967. The ultrastructural basis of capillary permeability studied with peroxidase as a tracer. J. Cell Biol. 98: 213-236.

Margulis, L., G. Thorington, B. Berger, and J. Stolz. 1978. Endosymbiotic bacteria associated with the intracellular green algae of Hydra viridis. Current Microbiol. 1: 227-232. 
Miller, L. T. 1984. Gas-liquid chromatography of cellular fatty acids as a bacterial identification aid. Hewlett-Packard Application Note. Pp. 228-237.

Moss, C. W. and V. Lewis. 1967. Characterization of Clostridia by gas chromatography. I. Differentiation of species by cellular fatty acids. Applied Micr. 15: 390-397.

Palincsar, E. E., W. R. Jones, and J. S. Palincsar. 1988. Bacterial aggregates within Aiptasia pallida. Am. Zool. 28(4): 149.

Pardy, R. 1976. The production of aposymbiotic hydra by the photodestruction of green hydra zoochlorellae. Biol. Bull. 151: 225-235.

Peters, E. C. 1984. A survey of cellular reactions to environmental stress and disease in Caribbean scleractinean corals. Helgol. Meeresunturs. 37: 113-137.

Peters, E. C., J. J. Oprandy, and P. P. Yevich. 1983. Possible causal agent of "White Band Disease" in Caribbean acroporid corals. $J$. Invert. Pathol. 41: 394-396.

Reynolds, E.S. 1963. The use of lead citrate at high $\mathrm{pH}$ as an electronopaque stain in electron microscopy. J. Cell Biol. 23: 271-288.

Sasser, J. M., D. H. Fieldhouse, and C. N. Carter. 1984. Computer assisted identification of bacteria based on fatty acid analysis. Phytopathology 74(7): 882 .
Southward, A. J., E. C. Southward, P. R. Dando, G. H. Rau, H. Felbeck, and $\mathrm{H}$. Flugel. 1981. Bacterial symbionts and low $13 \mathrm{C} / 12$ $\mathrm{C}$ ratios in tissues of Pogonophora indicate unusual nutrition and metabolism. Nature 293: 616-620.

Southward, E. C. 1986. Gill symbionts in thyasirids and other bivalve molluscs. J. Mar. Biol. Ass. 66: 889-914.

Soyer, J., M. Soyer-Gobillard, C. Theriot-Quievreux, M. Bouvy, and G. Cahet. 1987. Chemoautotrophic bacterial endosymbiosis in Spisula subtruncata. Ultrastructure, metabolic significance and evolutionary implications. Symbiosis 3: 301-314.

Thorington, G., B. Berger, and L. Margulis. 1979. Transmission of symbionts through the sexual cycle of Hydra viridis I. Observations on living organisms. Trans. Am. Microsc. Soc. 98(3): 401-413.

Vacelet, J. 1975. Etude en microscopie electronique de l'association entre bacteries et spongiaires du genre Verongia. J. Microscopie Biol. Cell. 23: 271-288.

Wilkerson, F. P. 1980. Symbionts involved in phosphate uptake by green hydra. Pp. 269-277 in Symbiosis and Cell Biology, Vol. 1, W. Schwemmler and H. E. Schenk, eds. Walter de Gruyter, Berlin.

Wilkinson, C. R. 1978. Microbial associations in sponges. Mar. Biol. 49: $161-185$. 


\section{$2 \mathrm{BHL}$ Biodiversity Heritage Library}

Palincsar, Edward E et al. 1989. "Bacterial Aggregates Within the Epidermis of the Sea Anemone Aiptasia pallida." The Biological bulletin 177, 130-140. https://doi.org/10.2307/1541840.

View This Item Online: https://www.biodiversitylibrary.org/item/17220

DOI: https://doi.org/10.2307/1541840

Permalink: https://www.biodiversitylibrary.org/partpdf/39197.

\section{Holding Institution}

MBLWHOI Library

\section{Sponsored by}

MBLWHOI Library

\section{Copyright \& Reuse}

Copyright Status: In copyright. Digitized with the permission of the rights holder.

License: http://creativecommons.org/licenses/by-nc-sa/3.0/

Rights: https://biodiversitylibrary.org/permissions

This document was created from content at the Biodiversity Heritage Library, the world's largest open access digital library for biodiversity literature and archives. Visit BHL at https://www.biodiversitylibrary.org. 